\title{
How Students' Difficulty in Implementing Mathematical Representations in Solving Problem of Statistical Content is?
}

\author{
Hatija Lohi ${ }^{1, *}$ Mardiyana $^{2}$ Ikrar Pramudya ${ }^{3}$ \\ ${ }^{1}$ Postgraduate of Mathematics Education, Faculty of Teacher Training and Education, Universitas Sebelas \\ Maret Surakarta, Indonesia \\ ${ }^{2,3}$ Faculty of Teacher Training and Education, Universitas Sebelas Maret Surakarta, Indonesia \\ *Corresponding author. Email: hatijalohi01@student.uns.ac.id
}

\begin{abstract}
Students' mathematical representation is one of the fundamental skills that must be had by the student in the $21 \mathrm{st}$ century. Mathematical representation skill is the ability to represent notations, symbols, tables, pictures, graphs, diagrams, equations, or other mathematical expressions into other forms. This study aims to analyze students' mathematical representation skills in solving statistical problems. This is qualitative research. The subjects of this study were 3 students of seventh grade in SMPN 16 Surakarta who represents the total data of this study. The chosen subject has difficulty in mathematical representation. The instruments used were questions tests and interviews that have been validated by two validators. Data were validated by triangulation methods by comparing data from various methods of data collection of the test results.
\end{abstract}

Keywords: Data presentation, Problem solving, Representation.

\section{INTRODUCTION}

Mathematical representation is a required skill for students because in the 21 st- century students must have the critical thinking skill and can solve problems in communication and collaboration as well as in creativity and innovation. Therefore, it requires higher skills in students learning innovation. Several practices of problem-solving can be achieved and practiced through mathematical representation skill [1] Mathematical representation shows the ability to interpret the physical phenomena verbally, mathematically, using symbols and images, [2] In mathematical learning, it requires mathematical representation ability to support problemsolving for restating a problem or mathematical object through such things like selecting, interpreting, and translating and using graphs, tables, pictures, diagrams, formulas, equations and concrete objects to express problems more clearly [3]. Mathematical representation is the most common ability used in mathematical learning [4]. Representation can help mathematical thinking for developing and expressing one's views about problemsolving [5]. Because in every problem solving, it is required a problem representation to obtain a solution of the problem. In other words, representation as an intermediary to find the right solution in problem-solving [6]. Mathematical representation is needed in the learning process to assist students in solving problems so that problem-solving indicators are needed in the learning. Therefore, it requires problem-solving training in improvement of data presentation materials.

Representation is important for students to have, but practically it is difficult. Through the result of observations and interviews conducted by the researcher before, it showed that students are still not able to express their ideas and concepts to develop and represent mathematical concepts, especially in material of data presentation into other representations [7] The students inability resulted a low level of mathematical representation. From study result, the low level of mathematical representation of the students, particularly the junior high school, it is found that almost half of the students are not able to convert mathematical symbols into images on the graphs and had not been able to convey their mathematical ideas using their language [8].

The indicators of mathematical representation ability are finding out the relation of various representation 
concepts and procedures, grasping the relation of mathematical topics, applying mathematic in other fields or in everyday life, understanding the equivalent representation of a concept, finding out the relationship between one procedure and another in everyday life, and applying the relationships of mathematical topics [9]. The indicators are as follows: able to use numbers and symbols to solve problems in everyday life, able to create and use representations in various forms (graphs, tables, charts, diagrams etc), and able to select, to apply, and to interpret mathematical representations in problemsolving [10]. Based on these indicators, the tested question in this subject is a test of mathematical representation ability which presents data in the form of diagrams or symbols and the problem-solving in the form of diagrams. Accordingly, it requires training and improvement of mathematical representation skill in data presentation.

Refers to the observation in SMPN 16 Surakarta, student's mathematical representation ability needs to be improved because the students often forgetting to determine the equation that will be used in problemsolving. Consequently, it is required a deep analysis of students' problem-solving process in mathematic learning and another supporting innovation for the learning.

This study aims to analyze students' mathematical representation ability in solving statistical problems. Mathematical representation ability in solving statistical problems focuses on data presentation material for the seventh grades students. This study needs to be carried out at this time because many students have difficulty solving problems in representing data in various forms of representation both in diagrams, graphs and tables.

\section{RESEARCH METHOD}

This study employed qualitative descriptive research. It studies things as they are without trying to give specific treatment [11]. This study describes the data factually without any manipulation [12].The subjects of this study were the seventh grades students of SMPN 16 Surakarta, who have been taken the data representation material. There were 30 students. The test is given to all subjects who have been taken the data presentation material. The Instruments of this study were test and interview guidelines. The test is a description using a mathematical representation indicator on the data presentation material, having three questions to find out the subject in solving the problem whereas the interview is conducted to find out more about the understanding of the subjects' mathematical representation ability in solving problems. Test instruments and interview guidelines are validated by two proficient lecturers in the field of learning devices. Revisions were considered to improve the instrument quality by clarifying the numbers, symbols and diagrams by the indicators of mathematical representation. The test questions contained three indicators of mathematical representation ability. Each question has one indicator that is adjusted to the data presentation material. The representation is presented in Table 1.

The technique of data collection in this study were tests and interviews. The tested content was the content

Table 1. Questions test of mathematical representation.

\begin{tabular}{|c|c|c|}
\hline No & Definition & Figure \\
\hline 1 & $\begin{array}{l}\text { Students of the seventh grade loves to buy snacks during } \\
\text { break time. } \\
\text { Their favourite snacks on Monday are: } \\
\text { Soto: } 5 \text { students } \\
\text { Chicken noodles: } 30 \text { students } \\
\text { Meatball: } 45 \text { students } \\
\text { Ice tea: } 80 \text { students } \\
\text { Present the data above in diagram, image, or symbol. } \\
\text { If } \boldsymbol{\Delta}=10 \text { students and } \boldsymbol{\nabla}=5 \text { students }\end{array}$ & Figure: soto, chicken noodle, meatball and, ice tea \\
\hline 2 & $\begin{array}{l}\text { The students of Junior High School get the allowance form } \\
\text { their parents. Here are the allowance of } 5 \text { students: } \\
\text { Adli: IDR } 15,000 \\
\text { Annisa: IDR } 25,000 \\
\text { Dewa: IDR } 35,000 \\
\text { Ilham: IDR } 40,000 \\
\text { Trisna: IDR 50,000 } \\
\text { From the allowance data above, present them in bar } \\
\text { diagram and line diagram. }\end{array}$ & 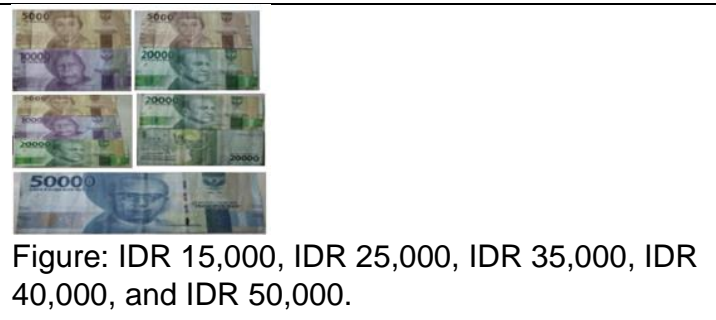 \\
\hline 3 & $\begin{array}{l}\text { Ahmad has IDR } 50,000 \text {. Then, he buys four books on the } \\
\text { different days and prices. The data are as follows: } \\
\text { Monday IDR } 10,000 \text {, } \\
\text { Tuesday IDR } 8,000 \\
\text { Wednesday IDR } 12,000, \\
\text { Thursday IDR } 20,000 \text {, } \\
\text { Present the data in a pie chart. }\end{array}$ & \begin{tabular}{l|l}
50000 & 1 \\
Figure: Ahmad's money is IDR 50,000
\end{tabular} \\
\hline
\end{tabular}


of data presentation. The researcher provided instruments in terms of data presentation questions with mathematical representation indicators to determine the subject's ability in solving the problem. The interview aims to find out more students' mathematical representation ability in solving problems. Data analysis was obtained by the test result, answer sheet observation, and deep interview. Data were analyzed by three stages, namely data reduction, data presentation (data display), and conclusion (verification) [13]. Data reduction is the first stage in analyzing, selecting and simplifying data in data research collection.

\section{RESULT AND DISCUSSION}

The results of this study are the data analysis of mathematical representation from the thirty research subjects obtained from test results and interviews conducted by the researcher, by noticing to the mathematical representation indicators. The presented subjects already represent the entire data. SP-1 is the subject with the highest difficulty, SP-2 has moderate difficulty, and SP-3 has the lowest difficulty.

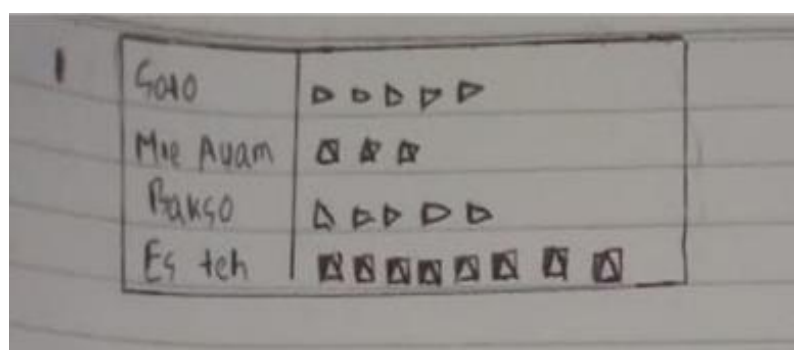

Figure 1 The working result of SP-1

SP-1 writes down important information from the Figure 1. The information of the first question, the used symbol for symbolizing soto, chicken noodles, meatballs and ice does not match with the question instruction. It is presumed that the subject does not understand how to use symbols and numbers. As a result, the subject uses inappropriate ones, but creating their own symbols. Based on the interview result with the subject, the subject considered that the symbols described for representing the numbers are described by row. If the first row is soto with one image, then the second row is chicken noodles with two images that are combined as well as on the third row. the image of meatball is one, and on the fourth row two images of ice tea are merged accordingly it is formed as in Figure 1. It strongly indicates that the subject has a very low problem-solving ability.

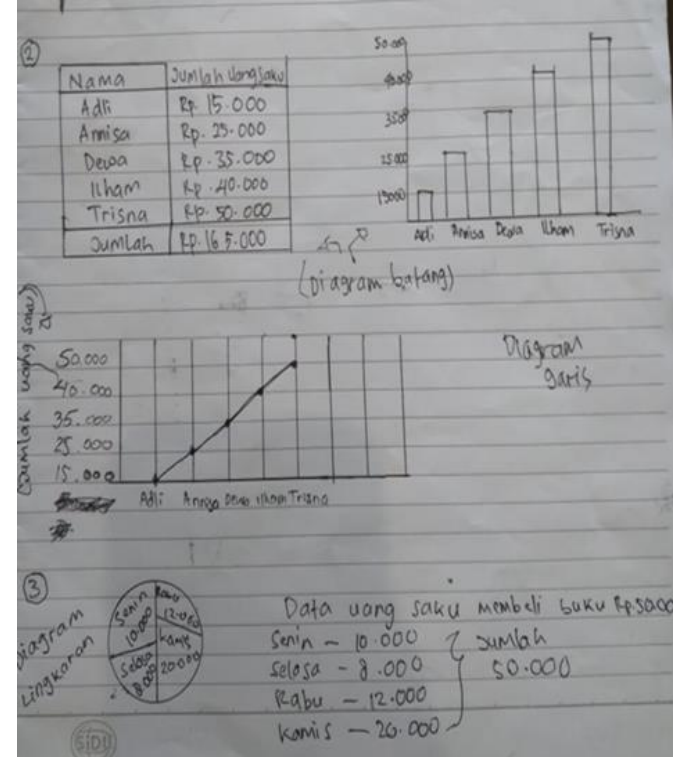

Figure 2 The working result of SP-1

SP-1 writes down important information from Figure 2. Information of the second question, subject uses the appropriate bar diagram. However, in the line diagram, the subject adds other lines. It is assumed that the subject considering the line diagram as same as the bar diagram. In the number writing, there is no point of 0 but immediately writes 15,000 while in the third question, the subject immediately writes the problem into a pie chart without completing it first. The interview result with the subject states that on second and third questions, the subject is not very familiar about line diagrams and pie charts because the subject does not pay attention during the lesson. The subject has very low problem-solving skills so that the subject only describes the line diagram according to what he remembers. The student is not able to have the solution so that student directly fill question in the pie chart without completing it first.

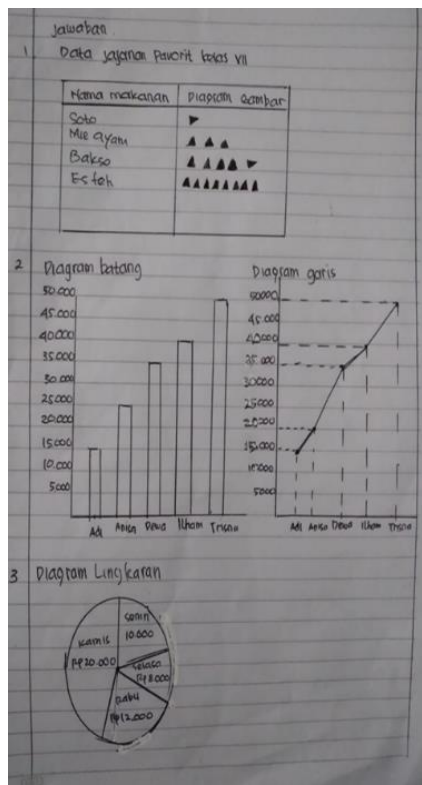

Figure 3 The working result of SP-2 
SP-2 writes down two important pieces of information as stated in the Figure 3. The subject has understood the first question and has correctly completed the bar diagram in the second question. However, the subject does not understand yet about line diagram so that the subject makes the dot lines as a link. In the third question, the subject only draws the circle and inserts the question into the bar diagram. It is assumed that the subject has difficulty using mathematical representations into the bar diagram and difficult in solving the problem. Based on the interview result, the subject reveals that the first question is quite easy but the subject does not know the representation of the line diagram due to it is similar with another material. As a result, the subject thinks that a line diagram should connect the vertical and horizontal lines.

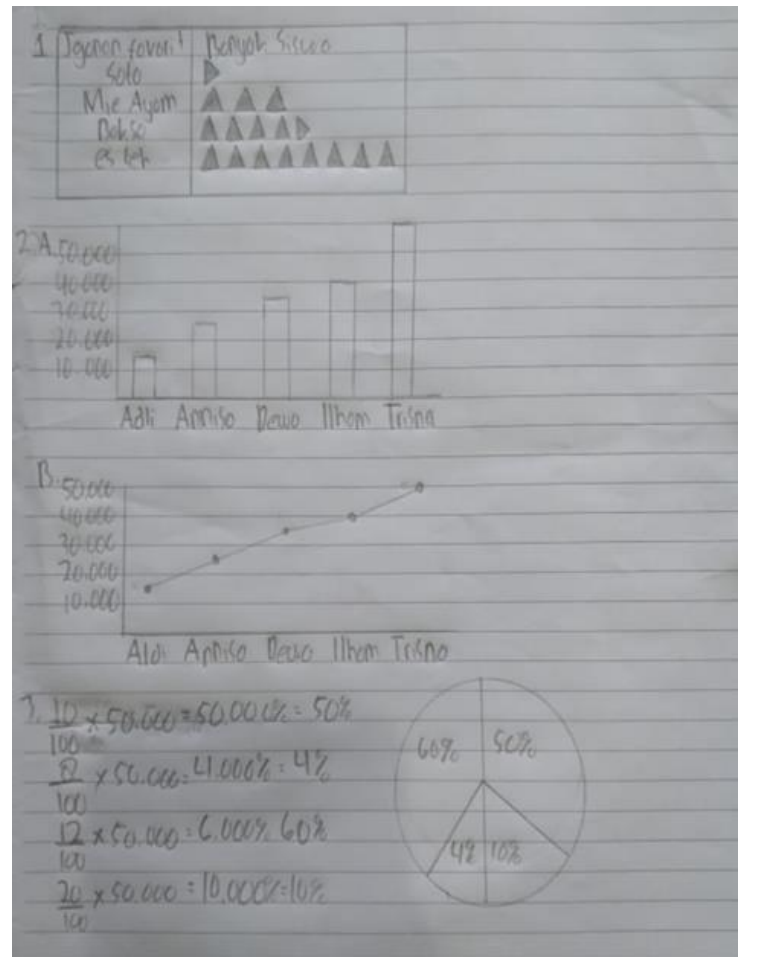

Figure 4 The working result of SP-3

SP-3 writes the information as seen in the following Figure 4. In the third question, the subject makes an error in the calculation. Pie chart should be calculated by degree. However, the subject uses percentage as the solution. It is assumed that the subject has difficulty in selecting, applying, and translating mathematical representations to solve the problem. Based on the interview result, the subject thinks that the solution was similar to calculating the percentage so that all the data divided by 100 , then multiplied by the total data and made as a percentage. In fact, the percentage calculation was not written in the student's answer.

\section{DISCUSSION}

Mathematic learning in schools uses tricky examples to understand. In this study, analytical skills are needed to solve the arising problems. One of problem-solving skill which often used is mathematical representation ability. It simplifies in solving mathematical problems in the classroom [14]. Practice students' mathematical representation ability requires concrete examples that related in the real life, interactive and familiar to the students. Hence, this study applies mathematical representation analysis to find out students' difficulties in implementing mathematical representations in problem solving [15]. This illustrates that representation in problem solving is very fundamental. Because in problem solving process, mathematical representation is a useful tool [16]. Representation requires students to find out the mathematical ways of thinking and ideas both abstractly and concretely [6]. The experienced difficulty in mathematical representation is the lack of necessary knowledge in interpreting and connecting the representations in the real world by problem solving [17]. Another difficulty occurs because the subject does not understand the given basic material. Furthermore, the subject simply follows the existing procedures without connecting the representation material with experience in the real-life [7]. Understanding of these concepts can support the problem-solving abilities, one of them is mathematical representation. Mathematical representation is a way to combine mathematical symbols and structures using numbers, variables, and operating equations [18]. It can be seen in students' sheets answers. On test sheets, the students tend to straight away write down the equation and the final answer, so the answer is incorrect. In addition, the students are confused in determining the used equation, they directly tend to look for the final answer. Meanwhile, it is expected that students can apply more mathematical representation indicators, so it is easier and more systematic in solving problem. It can be said that study the data presentation material with representations can increase students' problem-solving speed. However, mathematical representations have not been implemented yet [19].

\section{CONCLUSION}

Based on the result and discussion, the researcher concludes that SP-1 has the difficulty in representing data in symbol, diagram, and also in solving problem. Meanwhile, SP-2 has difficulty in representing data in a diagram, and has difficulty to solve problem which is a pie chart solution. SP-3 is difficult to recall problemsolving in completing the pie chart.

\section{ACKNOWLEDGMENTS}

The writers would like to thank all the teachers, students and all parties of SMP N 16 Surakarta for allowing and helping the writer in the research process. 


\section{REFERENCES}

[1] A. N. W. Priyadi, H. Kuswanto, and Sumarna, "Android physics comics to train the mathematical representation ability on momentum and impulse of senior high school students," J. Phys. Conf. Ser., vol. 1440, no. 1, 2020, doi: 10.1088/1742$6596 / 1440 / 1 / 012041$.

[2] S. D. Fatmaryanti, Ashari, and V. S. Wahidah, "Students' representation based on high order thinking skills for the concept of light," J. Phys. Conf. Ser., vol. 1517, no. 1, 2020, doi: 10.1088/1742-6596/1517/1/012056.

[3] OECD, "Executive Reading for Change Across Countries Results From Pisa 2000," OECD Publ., p. 13.

[4] Intan Kusumawati, Putut Marwoto, and Suharto Linuwih, "Implementation Multi Representation and Oral Communication Skills in Department of Physics Education on Elementary Physics II," J. Mater. Sci. Eng. A, vol. 5, no. 2, pp. 60-64, 2015, doi: 10.17265/2161-6213/2015.1-2.008.

[5] D. P. Sari and Darhim, "Implementation of react strategy to develop mathematical representation, reasoning, and disposition ability," J. Math. Educ., vol. 11, no. 1, pp. 145-156, 2020, doi: 10.22342/jme.11.1.7806.145-156.

[6] S. D. Farahhadi, "Representasi Matematis dalam Pemecahan Masalah | PRISMA, Prosiding Seminar Nasional Matematika," Prism. Pros. Semin. Nas. Mat., vol. 2, pp. 606-610, 2019, [Online]. Available:https://journal.unnes.ac.id/sju/index.php/ prisma/article/view/29071.

[7] N. Rahmadian, Mulyono, and Isnarto, "Kemampuan Representasi Matematis dalam Model Pembelajaran Somatic, Auditory, Visualization, Intellectually (SAVI) | PRISMA, Prosiding Seminar Nasional Matematika," Prism. Pros. Semin. Nas. Mat., vol. 2, pp. 287-292, 2019, [Online].

Available: https://journal.unnes.ac.id/sju/index.php/prisma/art icle/view/28940.

[8] A. Fauziah, S. Musa, and Ramlah, "Meningkatkan Kemampuan Representasi Matematis Siswa Smp Menggunakan Teknik Visual Thinking Berbasis Komik," Pros. Semin. Nas. Mat. dan Pendidik. Mat., no. 3, pp. 437-442, 2018.

[9] C. E. Allen et al., "National Council of Teachers of Mathematics," Arith. Teach., vol. 29, no. 5, p. 59, 2020, doi: 10.5951/at.29.5.0059.

[10] B. Mainali, "Representation in teaching and learning mathematics," Int. J. Educ. Math. Sci.
Technol., vol. 9, no. 1, pp. 1-21, 2021, doi: 10.46328/ijemst.1111.

[11] Budiyono, Budiyono. (2017). Pengantar Metodologi Penelitian Pendidikan. UNS Press.Pengantar Metodologi Penelitian Pendidikan. Surakarta: UNS Press, 2017.

[12] M. N. Kholid, C. Sa'dijah, E. Hidayanto, and H. Permadi, "How are students' reflective thinking for problem solving?," J. Educ. Gift. Young Sci., vol. 8, no. 3, pp. 1135-1146, 2020, doi: 10.17478/JEGYS.688210.

[13] M. B. Miles and A. M. Huberman, An Expanded Sourcebook Qualitative Data Analysis, Second. London, 1994

[14] J. L. \& D. J. L. Booth, "The role of Problem Representation and Feature Knowledge in Algebraic Equation-Solving.," Elsevier J. Math. Behav., pp. 32 : 415-423, 2013.

[15] Ninla Elmawati Falabiba, "Representasi Dalam Pembelajaran Matematika," vol. 01, no. 2, pp. 3344, 2019.

[16] M. A. Shiakalli and K. Zacharos, "Building meaning through problem solving practices: The case of four-year olds," J. Math. Behav., vol. 35, pp. 58-73, 2014, doi: 10.1016/j.jmathb.2014.05.001.

[17] D. De Bock, W. Van Dooren, and L. Verschaffel, 'Students' understanding of proportional, inverse proportional, and affine functions: two studies on the role of external representations," Int. J. Sci. Math. Educ., no. December, pp. 1-23, 2013.

[18] D. P. Utomo and D. L. Syarifah, "Examining mathematical representation to solve problems in trends in mathematics and science study: Voices from Indonesian secondary school students," Int. J. Educ. Math. Sci. Technol., vol. 9, no. 3, pp. 540 556, 2021, doi: 10.46328/IJEMST.1685.

[19] A. F. Samsuddin and H. Retnawati, "Mathematical representation: The roles, challenges and implication on instruction," J. Phys. Conf. Ser., vol. 1097, no. 1, 2018, doi: 10.1088/1742$6596 / 1097 / 1 / 012152$. 